Journal of Environmental Science and Public Health

doi: $10.26502 /$ jesph. 96120023

Volume 1, Issue 4

Research Article

\title{
Socio-Demographic Characteristics of Households as Determinants of Access to Water, Hygiene and Sanitation in So- Ava, Benin
}

Luc O. Sintondji $1^{*}$, Expédit Vissin ${ }^{2}$, Oswald F. Dan ${ }^{1,4}$, Elliott R. Dossou-Yovo ${ }^{1,3}$ and Dodji Amouzouvi $^{4}$

${ }^{1}$ Laboratory of Hydraulics and Water Control, National Institute of Water, University of Abomey-Calavi, BP 526, Cotonou, Benin

${ }^{2}$ Laboratory Pierre Pagney: Climate, Water, Ecosystem and Development (LACEEDE), University of AbomeyCalavi, 03- BP. 1122. Jericho, Cotonou- 03, Bénin

${ }^{3}$ Africa Rice Center, 01 B.P. 2551, Bouaké 01, Côte d'Ivoire

${ }^{4}$ Laboratory of Analysis and Research, Religions, Space and Development, University of Abomey-Calavi, BP 526, Cotonou, Benin

*Corresponding Author: Luc O. Sintondji, Laboratory of Hydraulics and Water Control, National Institute of Water, University of Abomey-Calavi, BP 526, Cotonou, Benin, Tel: + 22997195578; E-mail: o_sintondji@yahoo.fr

Received: 02 October 2017; Accepted: 01 November 2017; Published: 11 November 2017

\begin{abstract}
Adoption of good hygiene and sanitation practices is a major determining factor in household well-being and development of community members. In this study, the influence of socio-demographic factors on household hygiene and sanitation behaviour was assessed using interviews. The results revealed that $68 \%$ of households did not cover their containers during the transport of water; $58 \%$ of respondents defecated in water and $31 \%$ in the open air. Only $40 \%$ of households washed their hands with water and soap after defecation; $42 \%$ of respondents discharged their wastes into the water body while $34 \%$ discharged them into the natural environment; $49 \%$ of the respondents evacuated their wastewater into the water body while $51 \%$ preferred to pour them into the wild. Most of the practices of the populations were not conducive for ensuring healthy drinking water quality and preserving their
\end{abstract}


health mainly due to their low educational level. Improvement of household socio-economic status and access to education, enhancing the capacity of water and sanitation personnel and community groups to achieve and sustain equitable access to, and use of, improved drinking water and basic sanitation and adoption of improved hygiene practices would contribute to the reduction of water borne diseases.

Keywords: Benin; Drinking water; Household; Hygiene; Sanitation

\section{Introduction}

Water is a natural element of primordial importance, indispensable to every form of life. It constitutes a resource necessary for all human activities and a determinant production factor for sustainable development [1]. Access to safe drinking water is undoubtedly beneficial to health [2]. Drinking good water quality is paramount to human health, especially as pollution risks exist at every stage of the supply chain [1]. According to Makoutodé [3], the conditions for the collection, transport, storage and handling of drinking water can contribute to its pollution. Although it may have a clear appearance and no odour or flavour, the water collected may contain elements that may have adverse health effects, such as pathogenic microorganisms, undesirable substances or even toxic substances [4].

In Benin, many people still use water from wells or watercourses as drinking water, even in cities [5]. This is particularly the case in the lake commune of Sô-Ava located in the department of the Atlantic in southern Benin. The drinking water supply coverage in the whole commune is $49.43 \%$ and the access rate to household latrines is $14.57 \%$ [6, 7]. In terms of hygiene and sanitation, the situation is very unreliable in that barely $10 \%$ of household is equipped with family latrine and has access to sewage disposal facilities (sumps, lost wells). Additionally, household solid and biomedical wastes are poorly managed [7].

Household social and economic variables are also associated with toilet facility and waste disposal pattern, which can directly affect water quality. Socio-demographic studies of household water quality may help answer questions about variations at community and household level in water acquisition, use and quality. Such research can lead to more efficient design and targeting of household and community training about water sources, safe use and storage as well as waste disposal. The purpose of this paper was to assess the influence of socio-demographic factors on the hygienic behaviour of households in the drinking water-supply-chain and sanitation.

\section{Materials and Methods}

This research was carried out in the commune of Sô-Ava which is located in the department of the Atlantic in the south of Benin. The commune occupies the lowland of the Ouémé River and the river Sô to which it owes its name. It extends over an area of $218 \mathrm{~km}^{2}$, on which lives a population of 118,547 inhabitants with a density of about 567 inhabitants per $\mathrm{km}^{2}$ [8]. It is bounded in the north by the communes of Zè, Dangbo and Adjohoun, in the south by the commune of Cotonou, in the east by the lake commune of Aguégués and in the west by the municipality of 
Abomey-Calavi. The climate is characterized by the alternation of two rainy seasons and two dry seasons. The large rainy season extends from March to July and the small season from September to November. The mean annual air temperature and precipitation are $27^{\circ} \mathrm{C}$ and $1346 \mathrm{~mm}$, respectively (data from 1986 to 2015).

The target population of the study is the households in the commune of Sô-Ava. Two sampling methods were used: the non-probabilistic method and the probabilistic method. Sampling through non-probabilistic method covered all the districts of the commune. Interviews were made on the difficulties related to access to water, hygiene and sanitation with the village chiefs, some councillors, the leaders of the women's groups, the community relays and other water users. Sampling through the probabilistic method was conducted to identify the households for in-depth interviews. The total population of the commune of Sô-Ava is roughly 118,547 inhabitants divided into 20,356 households [8]. The sampling method used in this study is stratified simple random sampling [9]. The size of the sample (n) was determined using the equation $1[10]$ :

$n=\frac{U_{1-\alpha / 2}^{2} \times p(1-p)}{d^{2}}$

where $\mathrm{n}$ is sample size; $\mathrm{U}_{1-\alpha / 2}^{2}=3.8416$ is the value corresponding to a confidence level of $95 \%$; $\mathrm{p}$ is the proportion of households with access to a source of drinking water in Sô-Ava and dis the desired accuracy $=5 \%$.

The municipality of Sô-Ava comprised 42 villages, we chosen 42 strata at the rate of one stratum per village. Thus, the number of households to be surveyed is equal to 384.11 households, i.e. a total of 400 households, proportionally distributed among the 07 districts and 42 villages in the municipality of Sô-Ava.

The dependent variables included: hygiene behaviour (cleanliness of the container, whether the container is covered during transport, materials and location of the storage container, cleanliness of the collection cup, washing of hands before eating and after handling stools); sanitation practices (place of defecation, existence of latrines, cleanliness of latrines, method of evacuation of waste water and household waste). The independent variables included sociodemographic characteristics: sex, level of education and size of the household.

Direct observations of household conditions, semi-structured and structured interviews and focus group interviews were used for data collection based on observation grid and questionnaire. The results were entered in the Excel spread sheet and then the statistical processing was done with the statistical software SPSS 17 (Statistical Package for Social Sciences). The descriptive statistics were used for calculating the frequencies of statistical units; creating round tables with the selected variables and estimating the correlation between selected variables and comparing them using the Pearson $\mathrm{Chi}^{2}$ test or Fisher's exact test with a significance level of 0.05 . 


\section{Results}

\subsection{Socio-demographic characteristics of respondents}

The socio-demographic results from the household survey revealed that the number of heads of households surveyed was 78 (i.e. $19.4 \%$ of the respondents) and that there were 322 women ( $80.6 \%$ of the respondents), of a total of 400 households who were interviewed throughout the commune of Sô-Ava. Most of the socio-cultural groups in the commune were Toffin, who accounted for $95.8 \%$ of respondents followed by Aïzo (1.7\%) and Fon (1.1\%). There were also other ethnic groups such as Yoruba $(0.6 \%)$ and Wémè $(0.6 \%)$. Regarding the level of education, $80.9 \%$ of respondents had never been to school. An estimated $10 \%$ of respondents completed primary school, $8 \%$ completed secondary school, and $1 \%$ completed higher education. Trade is the main activity carried out by $66.2 \%$ of the respondents. There were also handicrafts such as sewing, hairdressing, painting, mechanics, photography and mouldings which represented $11.1 \%$ of the respondents' activities followed by fisheries $(9.1 \%)$ and agriculture (3.9\%). The number of educated people (pupils, students, teachers, civil servants and health workers) in the commune accounted for only $3.3 \%$ of the respondents. The category of remaining actors that represented $6.4 \%$ of the surveyed population included homemakers, traditional healers among others. Fifty two percentage of the households surveyed had between 04 and 07 respondents. Twenty eight percentage of the respondents had a family size varying from 8 to 11 while only $11 \%$ of the respondents had a family size less than 03 . Households whose size is equal to or greater than 12 persons are of the order of $9.4 \%$.

\subsection{Hygiene and water supply}

The main source of water supply in the commune of Sô-Ava was drilling. It was the most widely used water source for drinking, cooking, laundry, dishwashing and showering. During the rainy season, it was only used for drinking and cooking food. For uses such as laundry, dishes and shower, people preferred to use rainwater. Wells were the prevailing water source in all the districts in the dry and rainy seasons (Figures 1 and 2) except for the Sô-Ava district, which was the only one to have the SONEB connections where wells were the second most important water source.

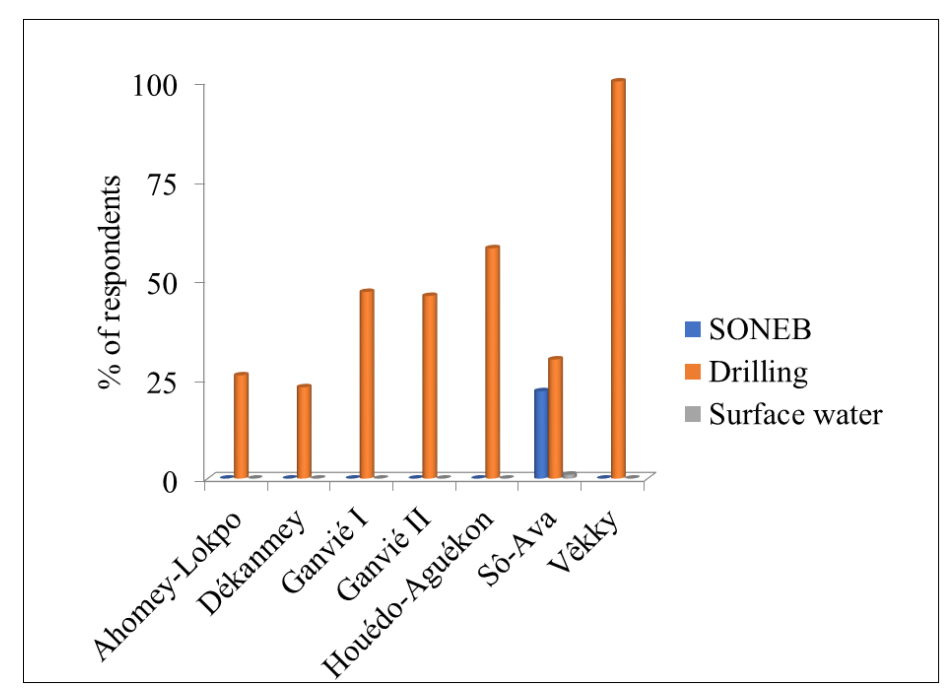

Figure 1: Source of drinking water supply in the different districts in the dry season. 


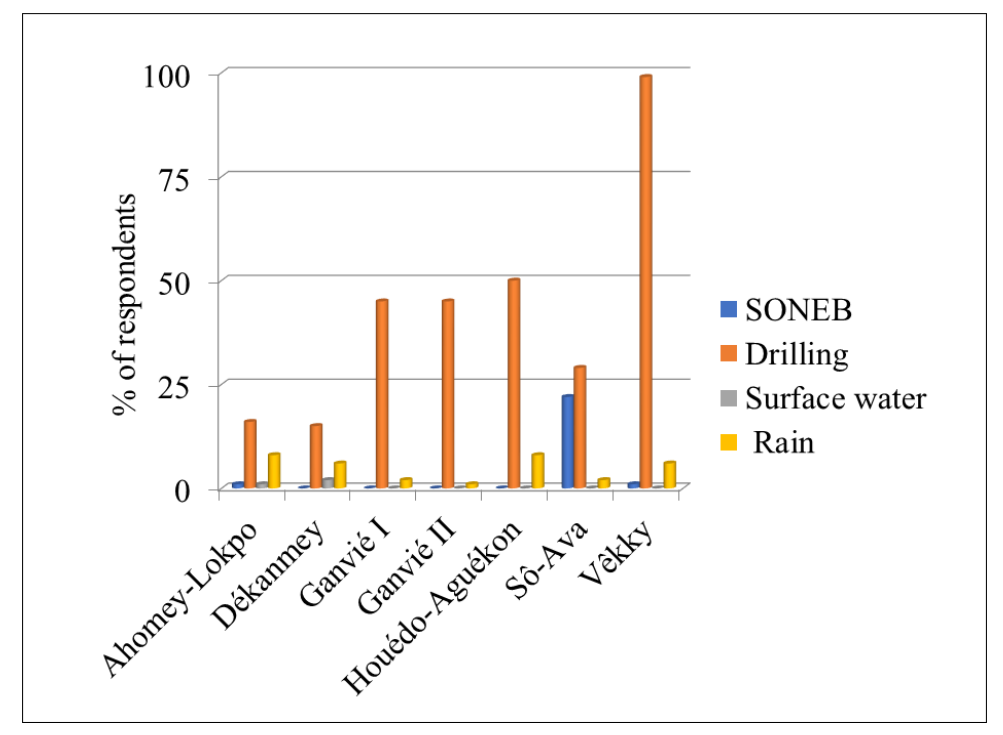

Figure 2: Source of drinking water supply in different districts during the rainy season.

In the municipality of Sô-Ava, water-related chores were made by $58.7 \%$ of women; $0.8 \%$ of men and $40.5 \%$ of children. These statistics at the municipal level did not accurately reflect the variation among the districts. In 04 districts of the municipality of Sô-Ava, more than $40 \%$ of children were responsible for supplying drinking water to their household. These were Ganvié II (43\%); Ganvié I (47\%); Ahomey-Lokpo (50\%) and Houedo-Aguékon (57\%) (Figure 3).

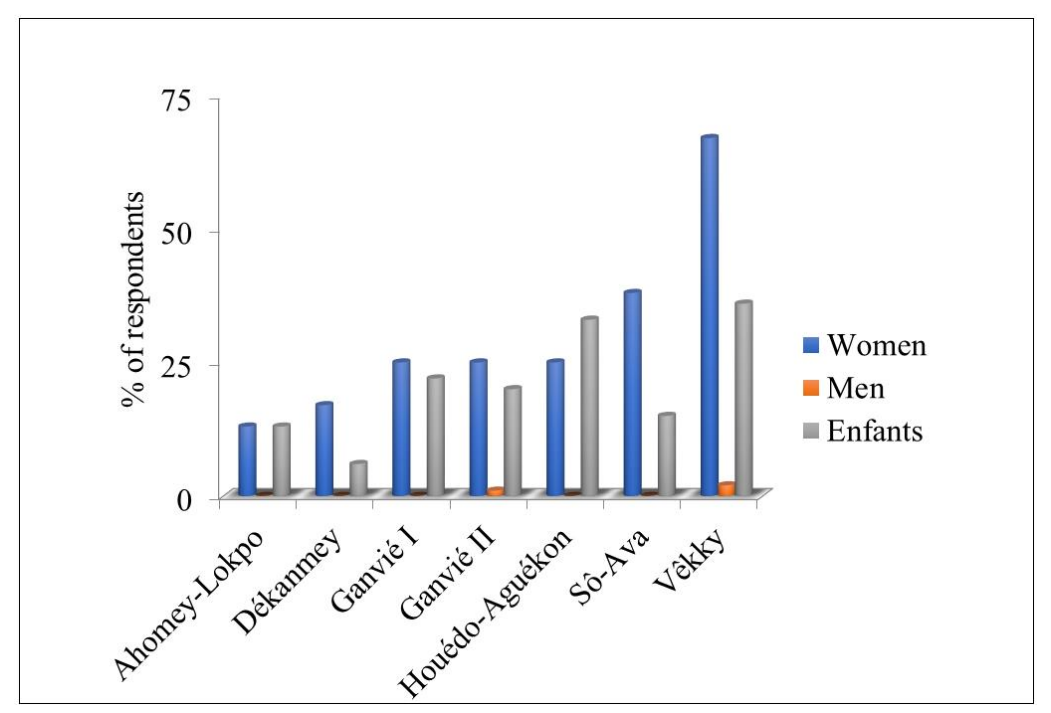

Figure 3: Percentage of people in charge of drinking water supply in each district.

The main difficulty evoked by the respondents was the long queue (52\%); followed respectively by the distance between the concession and the nearest water point (18\%), repeated water cuts (17\%) and high-water costs (11\%) 
(Figure 4). Two percentage mentioned other reasons such as the absence of a pirogue to facilitate the transport of water, the frequent unavailability of those who sell water and repeated failures of equipment to supply water points.

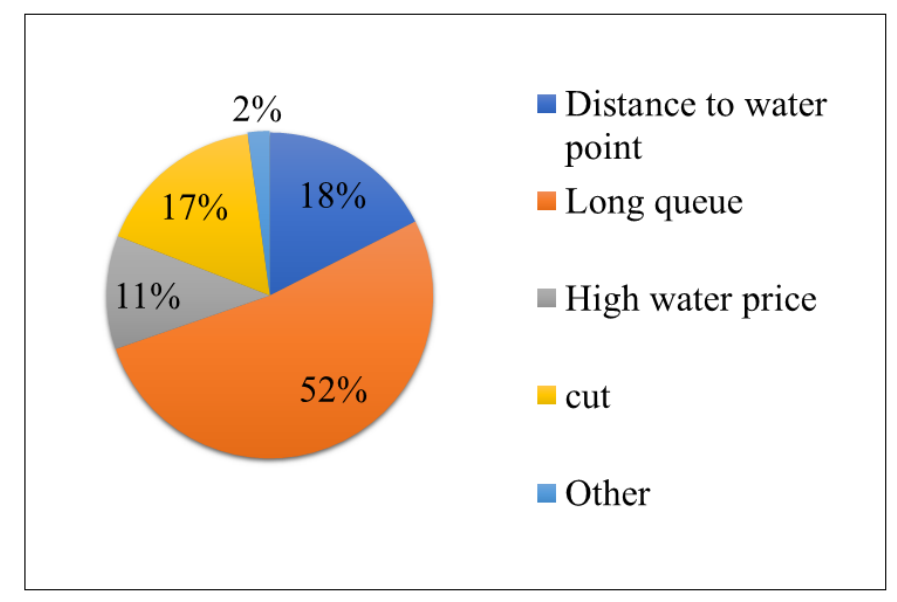

Figure 4: Difficulties related to the supply of drinking water in the municipality of Sô-Ava.

Figure 5 showed that the long queue is a widespread problem in most of the districts except for Sô-Ava where the main difficulty was the high price of water followed by the repeated cuts of water and the long queues. Beyond the long queue, which was the main difficulty faced by households in Ahomey-Lokpo - Dékanmey - Ganvié I and Ganvié II districts, the communities living in these localities were also far from the water points. However, in the Houedo-Aguékon and Vêkky districts, the second difficulty that households encountered after long queues was the repeated cut of water.

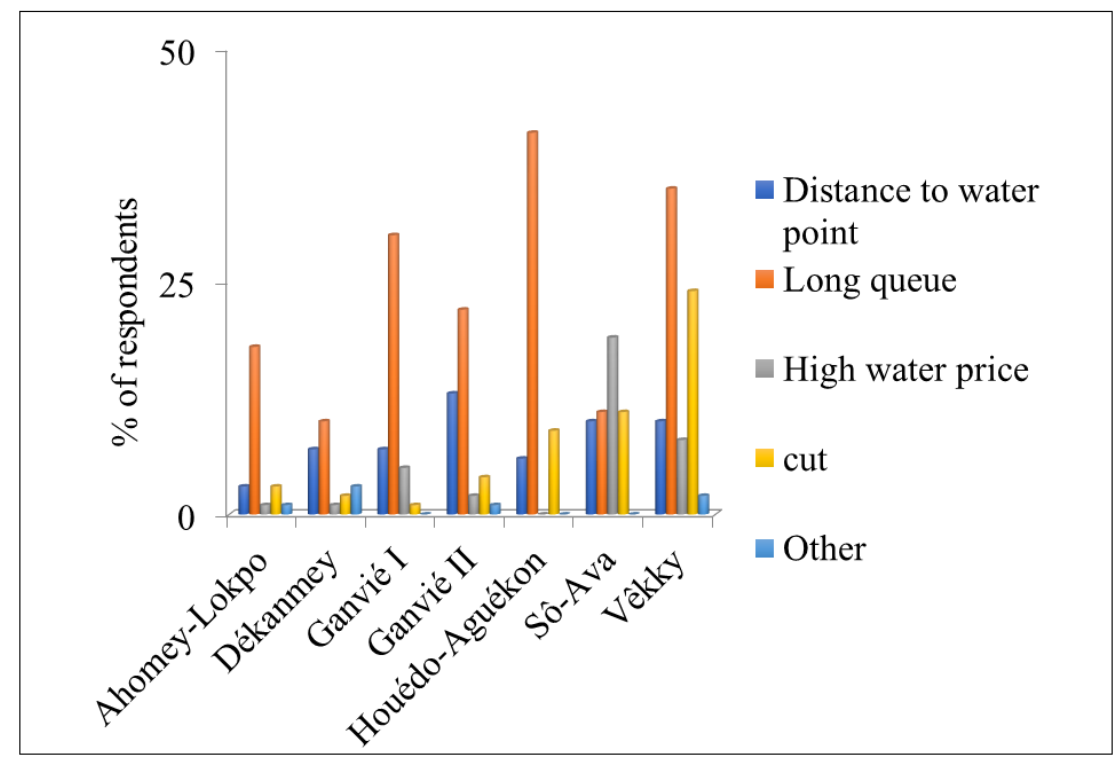

Figure 5: Difficulties related to the supply of drinking water within each district. 
This showed that the problems encountered by the population varied with their location and suggested the need to propose solutions based on the realities and the socio-cultural context in each district.

The results of the analysis of the types of containers used by the households in the municipality for the transport of water indicated that $4.7 \%$ of respondents used cans, $64.2 \%$ of users used uncovered containers compared to $26.9 \%$ who covered them and $4.2 \%$ of users who used none of the packaging mentioned. However, it was in the districts of Ganvié I and Ganvié II that the households which covered mostly their receptacles during the transport of the water were met. It is also important to mention that it was within these two districts that the cans were mostly used.

Approximately $97 \%$ of respondents washed their containers before water is drawn, as opposed to $3 \%$ who refrained from doing so. Of these $97 \%$ who washed their containers before going to collect water, washing methods varied from one household to another.

Water and soap were used to wash the inside and outside of containers by $68.7 \%$ of the respondents and only inside of the container by $25.4 \%$. However, water was used by only $2.6 \%$ of interviewees to wash the inside and outside of the container and by $3.4 \%$ of the respondents to clean the inside of the container.

Analysis of the data revealed that at the communal level, 68\% of households used uncovered containers during the transport of water compared to $32 \%$ which used covered containers. Among the $32 \%$ of respondents who used covered containers, $96 \%$ of the respondents used the lids of the containers and $4 \%$ used the plastic bags; $57 \%$ of households were located in Ganvié I and Ganvié II districts.

Among the various reservoirs used by households to store drinking water were plastic seals used by $87.2 \%$ of households followed by covered jars (7.8\%), followed by cans $(1.4 \%)$, uncovered jars $(0.8 \%)$ and containers made of aluminium and / or metal $(0.6 \%)$. The situation at the commune level was relatively similar in the different districts of Sô-Ava.

The survey results showed that $85 \%$ of the households surveyed used the cup that is usually placed on the lid, compared with $6 \%$ who used the cups that were not placed on the lid of the container; $1.3 \%$ of the respondents collected water directly from the tap while $2.3 \%$ chose to hang the cup at a peak and $6.3 \%$ preferred to store it elsewhere. The analysis of the results of the study showed that $78.2 \%$ of the households interviewed used the cup on the lid of the storage container to drink water, as opposed to the $21.8 \%$ of households remaining. $57.3 \%$ of respondents with clean cups took care to wash them more than 3 times a week, while those with acceptable hygiene did so three times and those with a poor hygiene practiced less than 3 washes per week or did not do it at for more than one week. Only 9\% of households surveyed used home water treatment techniques (Figure 6). Of those 9\% nearly $82 \%$ used water chlorination processes, $6 \%$ used traditional filtering methods, $6 \%$ used decanting techniques and the rest used other practices such as the use of alum (Figure 7). 


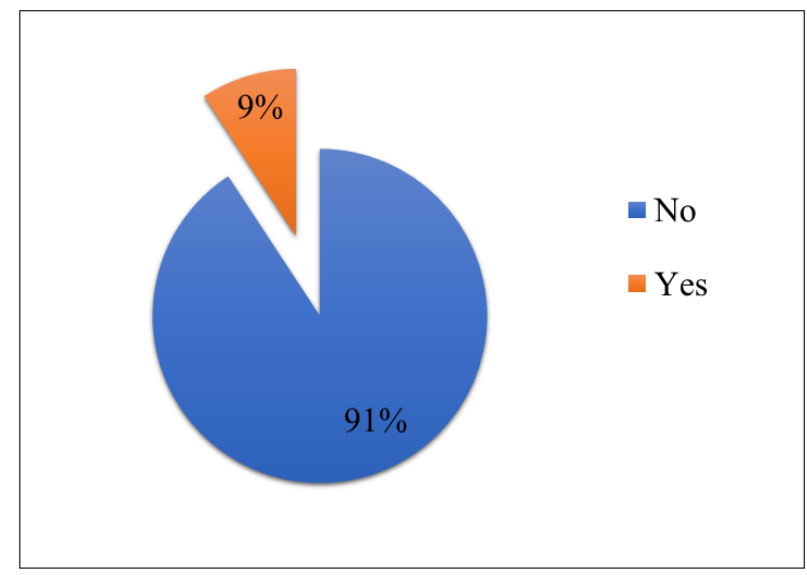

Figure 6: Frequency of households treating water before use.

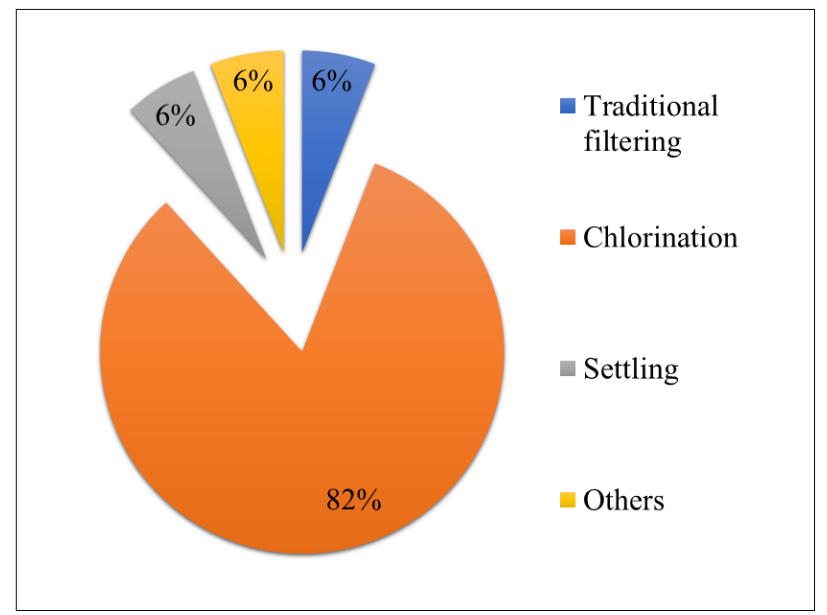

Figure 7: Types of treatments applied to the drinking water.

\subsection{Household environmental handling behaviour}

Figure 8 shows that $58 \%$ of the households defecated in water, $31 \%$ practiced open defecation, and the remaining $11 \%$ had access to latrines. Of the $11 \%$ who had access to latrines, $47 \%$ used improved latrines, $26 \%$ used latrines on stilts, $16 \%$ used modern flush toilets, and $11 \%$ defecated in rudimentary pits.

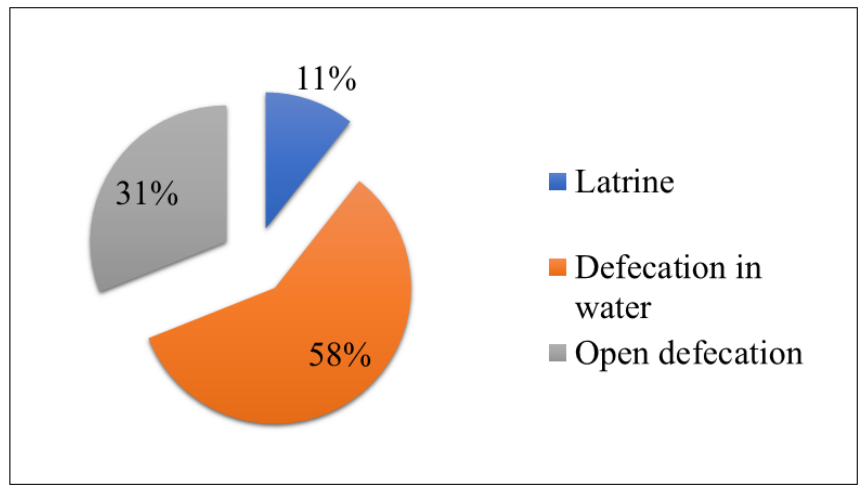

Figure 8: Location of household defecation place at the municipal level. 
The examination of Figure 9 shows that defecation in water was a common and frequent practice, mostly observed in the Ganvié I - Ganvié II - Houedo - Aguékon and Vêkky districts while open defecation was the most frequent in the districts of Ahomey-Lokpo - Dékanmey and Sô-Ava. The use of latrines by households was relatively low in all Sô-Ava districts. The observations made on the cleanliness of the latrines showed that nearly $60 \%$ of the latrines were dirty, $33 \%$ had an acceptable level of hygiene and $7 \%$ were clean.

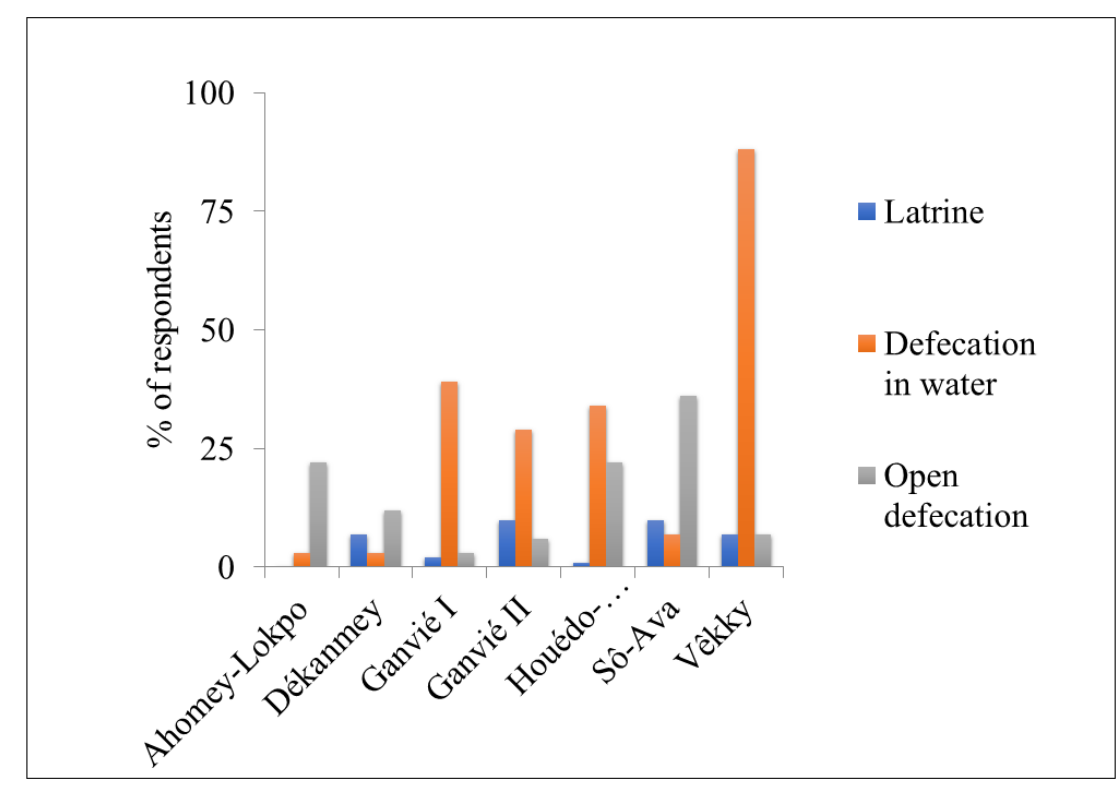

Figure 9: Location of household defecation within each district.

Of the $86 \%$ of households who reported hand washing after defecation, only $40 \%$ said they used water with soap and / or ash against $60 \%$ who rubbed their hands with water.

The information gathered from Sô-Ava households confirmed that malaria was the most common disease in the municipality and this throughout the year. In the dry season, $65 \%$ of the households surveyed suffered from malaria, $13 \%$ suffered from cholera while $12 \%$ had measles and the remaining $10 \%$ evoked illnesses such as allergies, fever, dermal diseases, coughs and colds. In the rainy season, malaria was prevalent at $94 \%$ in the commune; while cholera and fever each affected 3\% of the population and the remaining $1 \%$ alluded to ailments such as anemia, tension, dizziness, cough, diarrhea etc.

From the different answers obtained in this study concerning the attitude adopted by the households questioned in the case of diseases, about $13 \%$ of households practiced exclusively self-medication (herbal teas, tablets, etc.), $66 \%$ self-medication and in case of non-satisfaction went to a health center. Finally, $21 \%$ of respondents reported that they went directly to health centers as soon as the first symptoms of the disease appeared. 
The So river constituted the waste receptacle for $42 \%$ of the households surveyed, $34 \%$ dumped their waste in the wild while $21 \%$ practiced incineration and the remaining $3 \%$ used waste for landfilling, embankments of puddles water and / or the front of their concession. It should be noted that about $11 \%$ of respondents used the waste they produced to backfill puddles. Wastewater was discharged to the environment without any prior treatment with $49 \%$ of the surveyed population releasing them into the water body and $51 \%$ evacuating these waters to the environment. In terms of pre-meal precautions, $73 \%$ of respondents said they rubbed their hands with water only before eating. Only $26 \%$ washed their hands with soap and water or ash and $1 \%$ of respondents did not take any of these precautions. In almost all the districts of Sô-Ava, the situation was similar, since washing hands with water simply was the most common.

Household surveys were supplemented by field observations and group or focus group discussions in all the districts of the Sô-Ava commune. Observations revealed that basic hygiene practices in drinking water supply and sanitation were not often respected by the communities despite the various sensitizations that were made. In the commune of Sô-Ava, water is sold at 405 FCFA m ${ }^{-3}$ to farmers. Water is sold between 10 and 50 FCFA to households based on the volume of the bowl. Most of the fountains found reported that they usually sell between 10 to $16 \mathrm{~m}^{3}$ of water per week. The opening hours of the water points were from 6 Am to $12 \mathrm{Pm}$. Works were maintained monthly. Chlorination was the technique used to treat water. A great insalubrity was observed in the commune with the presence of the wild dumps lodging most alleys and alleys associated with the wandering of the animals which defecated everywhere. In addition, garbage and wastewater from households, animal carcasses, etc., which were usually dumped into the water body, were burnt or used to fill the bottom. In the case of water-borne diseases, the most common ones were malaria, diarrhea, cholera, typhoid fever, acute respiratory infections (ARI). The health workers interviewed told us that these ailments occurred throughout the year but the frequency was much higher in the rainy season (March-July) and in the period of flooding (August-December). The most vulnerable age group was children (less than years old) and pregnant women.

\section{Discussion}

The information collected during the surveys fell into two main categories: socio-demographic characteristics that considered gender, ethnicity, main activity, education level, household size and environmental characteristics that assessed the hygiene of drinking water, sanitation, environmental and food hygiene. Water hygiene was evaluated through the sources of drinking water, transport, storage, handling and water treatment techniques; sanitation considered the place of defecation, the use of family latrines and subsequent health issues; the hygiene of the living environment dealt with the mode of disposal of household waste and waste water and finally food hygiene addressed the precautions taken by households before food consumption.

\subsection{Socio-demographic characteristics}

Eighty percentage of the respondents were women and the average household size was 5 individuals. This average was close to the number of 5.8 persons per household reported by the INSAE [8]. The surveys that took place during 
this work were more interested in women than in men. The reasons for this choice were that women and men contributed in a different and often unequal way to water and sanitation management at both household and community levels. Women are typically those who manage water in households because they take care of water, make sure that it is sufficient, and adequately stocked. In terms of sanitation, although men take build the latrines, women are responsible of their maintenance.

The most common ethnic group is "Toffin", i.e. $95.8 \%$ followed by fon and Aïzo, which represent $2.8 \%$ of the respondents. These data are in line with those contained in the PDC [11] which specifies that the socio-cultural groups in the commune are Toffin (70\%), Fon and Aïzo (20\%). Concerning the main activity, it varied among respondents. The traders dominate with a percentage of $66.2 \%$. Other professions include crafts (hairdressing, sewing, photography, crafts, etc.); agriculture, fishing, students / pupils, public employees, private employees, etc. The proportion of $80 \%$ of women surveyed in the survey could explain the strong dominance of commercial activity. It is also noted that $81.2 \%$ of respondents have no educational attainment. Early marriage of girls, unwanted pregnancies, lack of follow-up by parents and poverty are factors contributing to the explanation of the low educational level.

\subsection{Water hygiene}

Access to drinking water is a key determinant in the improvement of health and hygiene and sanitation conditions for households. As Kofi Annan, former Secretary-General of the United Nations, said: "we will not conquer AIDS, tuberculosis, malaria or any other infectious disease in developing countries if we have not won the battle of drinking water, sanitation and basic health care". Thus, the right to water recognized by the United Nations is an adequate supply, physically accessible and affordable for every citizen. Yet the populations do not have equal access to healthy drinking water. According to the results of field surveys, the main source of drinking water used by the population is drilling. According to health data in 1999, sources of drinking-water that can be considered healthy are water installed inside or outside the dwelling, public taps, boreholes equipped with pumps and the wells protected. But it must be noted that there are still villages surveyed in the commune where households continue to use surface water (ponds, backwaters, rivers, rivers, lakes) as drinking water. The reasons given by the population are, on the one hand, linked to the fact that after a few hours, suspended particles are observed in the form of a reddish deposit in the drilling water, suggesting that it becomes free from impurity and can therefore be used as drinking water. On the other hand, the population believes that this source was used by their ancestors to whom it never caused diseases. According to the study by Makoutodé [3] in the prefecture of Grand-Popo in Benin, good conservation of drinking water requires the adoption of hygiene rules throughout the supply chain (collection, transport, storage and handling of water for consumption). The results of our surveys in the municipality of Sô-Ava showed that almost $94 \%$ of households washed the container for drinking water with soap and water; only $32 \%$ covered the container from the source to home. It was found that in the districts of Ganvié I and Ganvié II there is a high proportion of households covering their containers during transport. As these districts are lacustrine, the most suitable means of transport is boat or canoe and the population covers their receptacles at the risk of seeing its content poured into the boat or into 
the body of water. However, in addition to Ganvié I (43\%) and Ganvié II (47\%), the districts of Ahomey-Lokpo (50\%) and Houedo-Aguékon (57\%) were targeted as those where more than $40 \%$ of children are responsible of the supply of drinking water to their household. This situation is not without consequence on this youth especially on girls who are generally deprived of education because their mothers need them to fetch water during the day. Nearly 99\% of the respondents installed the covered plastic seals in their homes as storage containers. All households claimed to wash the storage container at least once every 3 days. As for home water handling, $85 \%$ of households recognized the common use of the cup on the storage container. These results are in line with those of Makoutodé [3], who reported in his work that $81 \%$ of households surveyed deposit the water collection container for consumption on the storage jar lid after drinking water. Adoko [12] highlighted that drinking cups are often poorly maintained and when water is consumed, it often happens that the user pours thousands of microbes into the container if his hands are dirty which exposes the water and its consumers to health's risks.

In a study carried out in the village of Boassa in Burkina-Faso in 1992 [13], it was found that drinking water collected at the pump by the population is contaminated during transport, storage and handling home. The causes mentioned were ignorance of the rules of hygiene and the use of unsuitable, open and unprotected containers. Thus Odoulami [14] reported that safeguarding the quality of the water used depends on the hygienic precautions taken by the consumer. Among the hygienic behaviours' that World Health Organization considers important for health, hand washing with soap is a top priority. It is difficult to monitor actual behaviour, but it is possible to measure the presence of water and soap at a designated location through household surveys. It has been shown to be a robust indirect indicator. In terms of food hygiene, the information collected showed that approximately $73 \%$ of respondents washed their hands only with water while $26 \%$ stated they used water with soap and / or ash to clean hands before eating meals.

Regarding hand washing after toilets, among those who said they washed their hands about $40 \%$ did it only with water. However, observations from our surveys revealed that most households were not equipped with hand washing devices other than those installed in community latrines, which lack functionality and use. Similarly, an assessment of hand washing devices near the latrines was carried out in the commune of Bonou by Fandohan [15] in 2010 and showed that only $1 \%$ of the households surveyed had a hand washing device close to latrines. The author concluded that rural populations are not aware of the importance of this practice and this situation could expose them to the risk of disease.

\subsection{Sanitation}

Many efforts need to be made in the commune in terms of sanitation to improve the access of the population to hygienic latrines and for a better management of waste (household refuse, waste water and storm water). The proof is that the household survey showed that $58 \%$ of the respondents defecated in water while $31 \%$ practiced open defecation and only $11 \%$ used latrines. These figures are close to those provided in the communal PHAC, which specifies that out of 100 households in the commune, less than 15 households have access to family latrines, i.e. a 
coverage rate of $14.57 \%$ [7]. It should be noted that the analysis of the results also showed that defecation in the water is most evident in the lake districts of Ganvié I and Ganvié II and semi-lacustrine: Houedo-Aguékon and Vêkky. On the other hand, defecation in the open air is dominant in the districts of Ahomey-Lokpo, Dékanmey and Sô-Ava. These two modes of defecation, which are widespread and adopted by $89 \%$ of respondents in the municipality, are justified by the insufficiency of sanitary infrastructures, lack of cleanliness and hygiene, constraints (lacustrine environment, absence of firm ground to construct works, no other choices than defecating in the water etc.); practices and customs (old and customary practice, lakeside lifestyle, preference for defecating in water, the use of latrines is reserved to the elites of the locality etc.). However, most interviewees acknowledged that this is a bad practice and have even confessed the difficulties they experienced, particularly during the rainy season and in times of flood, to make their needs in water or in nature. In the municipality of Sô-Ava, the management of garbage, wastewater and rainwater is virtually non-existent and are potential sources of pollution of the living environment and water resources. This is reflected in the absence of a pre-collection structure or NGOs for household waste. In addition, field surveys revealed that almost $42 \%$ of households dump their waste on the edge or in the water, $34 \%$ reject them on wild dumps, $21 \%$ practice incineration and the remaining $3 \%$ use waste for landfill or backfill of their storefronts or puddles. In a similar study carried out by Kèkè [16] in 2002, the garbage is deposited on unoccupied spaces giving rise to the formation of small heaps which serve as a place of comfort for the surrounding households. As for sewage, there are no drainage networks (sewers or gutters) in the municipality of Sô-Ava. The wastewater from toilets, kitchens and laundry is discharged by almost $49 \%$ into the water body and the remaining $51 \%$ is discharged into the environment (concessions or around houses). The water has become a receptacle for waste of all kinds (household refuse, human excreta and animal waste water, rejection of batteries etc.). These management methods are inadequate with environmental protection and could lead to enormous health risks for households.

\section{Conclusions}

This study assessed the links between socio-demographic factors and hygiene and sanitation behaviours' of the households located in the commune of Sô-Ava. The results revealed that the populations used inappropriate practices for conserving drinking water and have developed poor hygiene and sanitation behaviour mainly due to their low educational level and poor access to information. Improvement of household socio-economic status and access to education, enhancing the capacity of water and sanitation personnel and community groups to achieve and sustain equitable access to, and use of, improved drinking water and basic sanitation and adoption of improved hygiene practices would contribute to the reduction of water borne diseases. Further studies are required to analyse the physico-chemical and bacteriological qualities of drinking water and the impacts on public health.

\section{Acknowledgments}

We would like to thank the International Foundation for Science (IFS) for funding this project. 


\section{Author Contributions}

Oswald Dan, Luc Sintondji and Dodji Amouzouvi designed the protocol. Oswald Dan collected the data. Oswald Dan, Expedit Vissin and Elliott Dossou-Yovo analysed the data and drafted the manuscript. Luc Sintondji, Expedit Vissin and Dodji Amouzouvi supervised and participated in the writing of the manuscript. All authors read, commented on and approved the final manuscript.

\section{Conflicts of Interests}

The authors declare no conflict of interest. The founding sponsors had no role in the design of the study; in the collection, analyses, or interpretation of data; in the writing of the manuscript, and in the decision to publish the results.

\section{References}

1. Baziz N. Étude sur la qualité de l'eau potable et risques potentiels sur la santé : cas de la ville de BATNA. Mémoire de magister en dynamique des milieux physiques et risques naturels, Université de Batna Hadj Lakhder, Algérie (2008).

2. Dégbey $\mathrm{C}$, Makoutode $\mathrm{M}$, Agueh $\mathrm{V}$, et al. Facteurs associés à la qualité de l'eau de puits et prévalence des maladies hydriques dans la commune d'Abomey-Calavi/Bénin. Santé 21 (2011): 47-55.

3. Makoutodé M. Qualité et mode de gestion de l'eau de puits en milieu rural au Bénin. Cas de la souspréfecture de grand-popo. Médecine d'Afrique noire 46 (1999): 528-534.

4. Lanjri FA, Brigui J, El Cadi A, et al. Caractérisation physico-chimique et bactériologique des eaux souterraines de Tanger, Mater. Environ. Sci 5 (2014): 2230-2235.

5. Capo-Chichi B. Les Béninois ne sont pas tous égaux face au droit à l'eau, Lettre du Bénin (2009): 12-13.

6. Mairie de Sô-Ava. Programmation Communale Eau 2015 - 2017, Version provisoire (2014).

7. Mairie de Sô-Ava. Plan d'Hygiène et d'Assainissement Communal (2013).

8. Institut National de la Statistique et de l'Analyse Économique. Quatrième Recensement Général de la Population et de l'Habitation (RGPH, 4), Effectifs de la population des villages et quartiers de ville du Bénin (2013).

9. Fortin J. Recherche sociale: de la problématique à la collecte des données publiée dans L'ABC des méthodes d'échantillonnage -partie 2 (2008).

10. Dagnelie P. Statistiques théoriques et appliquées, De Boeck, Brussels (1998): 517.

11. Mairie de Sô-Ava. Plan de Développement Communal de Sô-Ava 2016- 2020 (2014).

12. Adoko IEN. Hygiène, assainissement et qualité des eaux de consommation dans les quatre arrondissements urbains de la commune de Ouidah. Mémoire de Master Environnement, Santé et Développement Durable, Université d'Abomey-Calavi, Bénin (2012). 
13. Empereur-Bissonet P, Salzman V, Monjour L. Application d'un nouveau matériel de transport de stockage pour l'amélioratiIon de la qualité de l'eau de boisson en milieu rural africain. Bulletin de la société de pathologie exotique 85 (1992): 390-394.

14. Odoulami L. La problématique de l'eau potable et la santé humaine dans la ville de Cotonou (République du Bénin). Thèse de doctorat unique en Géographie et Gestion de l'Environnement. Université d'AbomeyCalavi, Bénin (2009).

15. Fandohan I. Etude de la recrudescence de l'épidémie du choléra dans la commune de Bonou, Département de l'Ouémé au Bénin en 2010, Mémoire de Master Environnement, Santé et Développement Durable, Université d'Abomey-Calavi, Bénin (2011).

16. Kèkè E. L'érosion pluviale en milieu urbain : cas de la commune d'Abomey -Calavi, aspects, Impacts et Moyens de lutte. Mémoire de Maîtrise, Université d'Abomey-Calavi, Bénin (2002).

(C) 1 BY ${ }_{\text {BY }}^{\text {This article is an open access article distributed under the terms and conditions of the Creative }}$ 